\title{
Original article \\ Selection of lactic acid bacteria as a probiotic and evaluated its performance on gnotobiotic catfish Clarias sp.
}

\section{Seleksi bakteri asam laktat sebagai probiotik dan evaluasi kinerjanya pada ikan lele gnotobiotik Clarias sp.}

\author{
Enita Romasni Turnip ${ }^{1}$, Widanarni ${ }^{2}$, Anja Meryandini ${ }^{{ }^{*}}$ \\ 'Departement of Biology, Faculty of Math and Science, Bogor Agricultural University \\ ${ }^{2}$ Department of Aquaculture, Faculty of Fisheries and Marine Science, Bogor Agricultural University \\ Agatis Street, Bogor Agricultural University, Dramaga, Bogor 16680, Indonesia \\ *Email: ameryandini@yahoo.com
}

(Received July 6, 2017; Accepted April 16, 2018)

\begin{abstract}
This study aimed to select lactic acid bacteria (LAB) as a potential probiotic that producing anti-microbial compounds in order to treat motile aeromonads septicemia disease caused by Aeromonas hydrophila on catfish Clarias sp. and evaluated its performance on gnotobiotic catfish. The in vitro assay was done to select several $\mathrm{LAB}$ isolates based on antagonistic activity against pathogenic bacteria. The selected isolate was tested in vivo to observe their ability to improve growth performances of catfish. The study was conducted with five treatments consists of $\mathrm{K}$ - (normal catfish without addition probiotic, without challenge test), $\mathrm{K}+$ (normal catfish without addition of probiotic, with challenge test), Np (normal catfish with addition of probiotic and challenge test), $\mathrm{G}$ (gnoto catfish without addition of probiotic, with challenge test), and Gp (gnoto catfish with addition of probiotic and challenge test). The results showed that the addition of Pediococcus pentosaceus E2211 as selected probiotic could increase survival rate, specific growth rate, and immune response towards infection of A. hydrophila. The best survival rate after challenge test was obtained in $\mathrm{Np}$ and $\mathrm{Gp}$ treatments $(88.46 \%)$, followed by $\mathrm{G}$ treatment (65.38\%), while the $\mathrm{K}+$ was only $53.84 \%$. The conclusion of this study was P. pentosaceus E2211 potentially used as a probiotic candidate for normal and gnotobiotic catfish. The presence of normal microflora with P. pentosaceus E2211 in Np treatment showed the best probiotic performance with daily growth rate $3.28 \%$, feed conversion ratio 1.79 , and total intestinal bacteria reached $108 \mathrm{CFU} / \mathrm{mL}$ significantly different from other treatments $(\mathrm{P}<0.05)$.
\end{abstract}

Keywords: Aeromonas hydrophila, catfish, LAB, probiotic, screening

\begin{abstract}
ABSTRAK
Tujuan penelitian ini adalah menyeleksi bakteri asam laktat (BAL) sebagai probiotik potensial penghasil senyawa antimikrob guna menanggulangi penyakit motile aeromonad septicemia akibat Aeromonas hydrophila pada ikan lele Clarias sp. dan evaluasi kinerjanya pada ikan lele gnotobiotik. Pengujian in vitro dilakukan untuk menyeleksi beberapa isolat BAL sebagai kandidat probiotik berdasarkan aktivitas antagonis terhadap bakteri patogen. Isolat terpilih kemudian diuji in vivo untuk mengetahui kemampuannya dalam meningkatkan performa tumbuh ikan lele. Penelitian ini menggunakan rancangan acak lengkap dengan lima perlakuan, yaitu: K- (lele normal tanpa probiotik dan tanpa tanpa diuji tantang), $\mathrm{K}+$ (lele normal tanpa probiotik dan diuji tantang), $\mathrm{Np}$ (lele normal diberi probiotik dan diuji tantang), $\mathrm{G}$ (lele gnoto tanpa probiotik dan diuji tantang), dan Gp (lele gnoto diberi probiotik dan diuji tantang). Hasil penelitian menunjukkan pemberian probiotik terpilih BAL Pediococcus pentosaceus E2211 mampu meningkatkan sintasan, laju pertumbuhan, dan respons imun ikan lele terhadap infeksi A. hydrophila. Sintasan terbaik pascauji tantang diperoleh pada perlakuan Np dan Gp yaitu sebesar 88,46\%, diikuti perlakuan G sebesar $65,38 \%$, sementara pada $\mathrm{K}+$ hanya mencapai $53,84 \%$. Kesimpulan dari penelitian ini ialah isolat BAL terpilih $P$. pentosaceus E2211 berpotensi sebagai kandidat probiotik untuk ikan lele normal dan lele gnotobiotik Clarias sp. Keberadaan mikroflora normal yang berasosiasi dengan P. pentosaceus E2211 pada perlakuan Np menunjukkan kinerja probiotik terbaik dengan nilai laju pertubuhan harian 3,28\%, rasio konversi pakan 1,79 dan total bakteri usus mencapai $108 \mathrm{CFU} / \mathrm{mL}$ yang berbeda signifikan dibanding perlakuan lainnya $(\mathrm{P}<0,05)$.
\end{abstract}

Kata kunci: A. hydrophila, BAL, ikan lele, probiotik, seleksi 


\section{INTRODUCTION}

Catfish Clarias sp. is one of the leading commodities in freshwater fish with high demand and is already reared by the society. That high demand will be demanding in increasing catfish production to fulfill the demand (KKP, 2014). The increasing production of catfish intensively often experiences a variety of problems, one of them is disease attack. The disease that often attacks the catfish is motile aeromonads septicemia (MAS) disease, also known as redness blotches disease caused by A. hydrophila bacterial infection (Kusdarwati et al., 2017). Lukistyowati and Kurniasih (2012) stated that A. hydrophila affected freshwater fish rearing and often cause outbreaks of disease with a high mortality rate (80-100\%) in a short time (1 to 2 week). According to Anyanwu et al. (2015), the mortality range of catfish infected by $A$. hidrophila could reach $90 \%$ of mortality. Wahjuningrum et al. (2013) also reported that the infection of A. hydrophila on the density of $10^{4} \mathrm{CFU} / \mathrm{mL}$ can cause a mortality of juvenile catfish up to $50 \%$ of the population.

The use of antibiotics for MAS disease control continuously appear a variety of negative impacts such as the pathogen resistance and the accumulation of toxic residues (Hao et al., 2014). Therefore, it takes an alternative prevention for MAS disease that is effective, secure, inexpensive, environmental friendly and has no negative effects on consumers.

An effort that can be done to prevent the MAS disease is using lactic acid bacteria (LAB) as probiotics candidate (control agent) on the catfish (Suskovic et al., 2010). The species of lactic acid bacteria that has been widely utilized and has been successfully commercialized as a probiotic were from the genera of Lactobacillus and Bifidobacterium. This two species of bacteria has known as probiotics candidate that are safe and able to produce bacteriocin metabolite to inhibit the growth of pathogens and increase the host immunity (Hegarty et al., 2016; Gomez et al., 2016) therefore it can be utilized as an alternative to replace the antibiotics.

Lactic acid bacteria are the gram-positive bacteria, non-spore forming bacteria, anaerobic or facultative, rod-shaped or rounded bacteria, and produce lactic acid as an end product during the fermentation of carbohydrates process (Quinto et al., 2014). Tambekar and Bhutada (2010) added that the agent of anti-bacteria like lactic acid can inhibit the growth of pathogenic bacteria because it can lower the $\mathrm{pH}$, therefore, the pathogenic bacteria is difficult to survive. In this study, the performance of LAB as probiotics was observed in normal catfish and gnotobiotic catfish (Situmorang et al., 2014). According to Martin et al. (2016), the gnotobiotic animal is a group of germ-free animal and has no microorganisms living both inside and outside their body to control the microbial specifically so that the interactions between the host and the microbial can be seen clearly. In gnotobiotic catfish, the existence of good bacteria both outside their body and in their digest tracts was being abolished or reduced by using various types of antibiotics, therefore, the role of probiotic bacteria can be evaluated. This study aimed to select a few isolates of the LAB and to evaluate its performance through the catfish feed in normal catfish and in gnotobiotic catfish as an effort to control the A. hydrophila infection.

\section{MATERIALS AND METHODS}

\section{Isolate of bacteria}

The bacteria that used in this study were LAB isolates of Lactobacillus plantarum E1211, Pediococcus pentosaceus E1222, $P$. pentosaceus E2211, P. pentosaceus E5, $P$. pentosaceus $\mathrm{E} 7$, and $P$. pentosaceus E8, were a collection from Laboratory of Animal Biotechnology, Research Center for Biological Resources and Biotechnology (PPSHB), Bogor Agricultural University and A. hydropliha isolates that obtained from a collection of Fish Health Laboratory, Department of Aquaculture, Faculty of Fisheries and Marine Science, Bogor Agricultural University.

\section{The pathogenicity test}

The pathogenicity test carried out through in vitro test in blood agar plate. $\mathrm{LAB}$ isolates streaked on blood agar plate and incubated at $27-28^{\circ} \mathrm{C}$ for 24 hours. The pathogenicity marked from the formation of a clear zone around the colonies. Isolates that did not form a clear zone around the colonies were then selected to be tested further.

\section{Antagonistic test of lactic acid bacteria towards Aeromonas hydrophila}

The inhibited activity of LAB isolates towards A. hydrophila known on its size of the inhibited zone that was formed by using agar spot 
assay (Klose et al., 2010). Each of LAB isolate inoculated in $50 \mathrm{~mL}$ of liquid medium of man ragosa sharpe (MRS) and incubated at $37^{\circ} \mathrm{C}$ for 10 to 14 hours (the optical density reached 0.8 ), then it centrifuged at $7000 \mathrm{rpm}$ for 20 minutes to obtain free cell supernatant, it neutralized the $\mathrm{pH}$ ( $\mathrm{pH}$ reached 6.5) by using $1 \mathrm{~N} \mathrm{NaOH}$. Meanwhile, the culture of A. hydrophila (with a density of $10^{6} \mathrm{CFU} / \mathrm{mL}$ ) poured in trypticase soy agar (TSA) plate. After it became solid, agar spot assay on the media is made by using sterilized straw (with autoclave for 15 minutes at $121{ }^{\circ} \mathrm{C}$ and pressure of $15 \mathrm{lbs}$ ). Then free cell supernatant of volume $25,50,75$, and 100 $\mu \mathrm{L}$ inserted into each spot and incubated at 30 ${ }^{\circ} \mathrm{C}$ for 24 hours, observed, and measured the inhibited zones by using the ruler.

\section{The growth curve}

The bacterial growth curve aimed to find out the bacterial growth phases and to determine the harvesting time of the cells. A single colony bacteria inoculated into $20 \mathrm{~mL}$ of sterile media MRSB and incubated at $37{ }^{\circ} \mathrm{C}$ for 10 minutes. Then $10 \mathrm{~mL}$ of the cultured bacteria inoculated into $90 \mathrm{~mL}$ of sterile MRSB medium and incubated at $37{ }^{\circ} \mathrm{C}$. The growth of bacteria was observed every one hour by measuring the optical density based on absorbance value using a spectrophotometer at a wavelength of $620 \mathrm{~nm}$.

\section{The mixture of selected lactic acid bacteria in feed and the viability test}

The feed sterilized using an autoclave at $121{ }^{\circ} \mathrm{C}$ and $15 \mathrm{lbs}$ of pressure for 15 minutes. The density of probiotics that added to feed was $10^{8}$ and $10^{10} \mathrm{CFU} / \mathrm{mL}$. The determination of probiotics density was based on the results of the calculation of total plate count (TPC) after several hours of incubation, then was diluted using phosphate buffer saline (PBS). The selected lactic acid bacteria inoculated on MRSB medium and incubated at $37{ }^{\circ} \mathrm{C}$. The cultured bacteria was then centrifuged at 7000 rpm for 20 minutes, the cells were taken and re-suspended with $\mathrm{PBS}$ in which obtained the concentrations of $10^{8}$ and $10^{10} \mathrm{CFU} / \mathrm{mL}$. As many as $1 \%$ of probiotics and $2 \%$ of egg whites as the adhesive sprayed onto the feed. After LAB was being mixed in feed, the viability of the bacteria tested through it took $1 \mathrm{~g}$ of feed to be diluted into $9 \mathrm{~mL}$ of $0.85 \% \mathrm{NaCl}$ and 0.1 $\mathrm{mL}$ of bacterial suspension streaked on MRS solid medium and incubated for 24 hours at 37 ${ }^{\circ} \mathrm{C}$, and then the colonies of the bacteria were calculated.
The determination of lethal dose $50\left(\mathrm{LD}_{50}\right)$ of Aeromonas hydrophila towards the catfish

The pathogenicity of A. hydrophila in catfish was tested by determining the lethal dose 50 $\left(\mathrm{LD}_{50}\right)$ that indicated by the bacterial density caused $50 \%$ of fish mortality. The catfish injected with A. hydrophila $\left(10^{5}, 10^{6}, 10^{7}\right.$, and $10^{8} \mathrm{CFU} /$ $\mathrm{mL}$ ) through intramuscular injection and reared for 10 days in the aquarium (sizing $60 \times 30 \times 40$ $\mathrm{cm}$, containing $10 \mathrm{~L}$ of water with a stocking density of each aquarium was 10 fishes). The observation is done every day to obtain the mortality of fish. The concentration of $A$. hydrophila that was obtained from the $\mathrm{LD}_{50}$ test as much as $10^{6} \mathrm{CFU} / \mathrm{mL}$ used as the infection dose of A. hydrophila upon the challenge test of catfish.

\section{The experimental preparation of normal catfish and gnotobiotic catfish}

The experimental fish that used in this study had two treatments i.e. normal catfish and gnotobiotic catfish. The preparation for gnotobiotic catfish was done by adding different types of antibiotics into the water, they were 250 $\mathrm{mg} / \mathrm{L}$ of ampicillin, $125 \mathrm{mg} / \mathrm{L}$ of rifampicin, and $250 \mathrm{mg} / \mathrm{L}$ of chloramphenicol for the reduction of bacteria in the outside part of the fish body. After that, the fish was being fast for 24 hours, until then they were given feed that containing $100 \mu \mathrm{g} / \mathrm{mL}$ of rifampicin for the reduction of the bacteria in the digestive tract for 4-5 days (Afrilasari, 2017). The utilization of rifampicin is based on the sensitivity result of catfish's intestinal bacteria that showed the intestinal bacteria of catfish tend to be sensitive to rifampicin more than other antibiotics.

\section{The preparation of experimental feed}

The feed used for the study were commercial pellet 781 (from the production of PT. Central Pangan Pertiwi) with $31-33 \%$ of protein content. The probiotic dose that used was as much as $1 \%$ in $100 \mathrm{~g}$ of total feed (Wang, 2007). The feed preparation included spraying the probiotics as much as $1 \%$ with a density of $10^{8} \mathrm{CFU} / \mathrm{mL}$ in the feed and the addition of $2 \%$ of egg white as an adhesive.

\section{In vivo test in catfish}

Catfish that used in the study was from catfish farmers in Dramaga, Bogor. Fish acclimated to experimental condition for a week before being given the treatment. The average weight was $8.76 \mathrm{~g}$ and reared in aquariums sizing $60 \times 30 \times 40$ $\mathrm{cm}^{3}$ with a density of 15 fishes/aquarium. The 
fish reared for 30 days and fed three times a day (in the 08.30 a.m, 14.00 a.m and 19.30 pm, night) with feeding rate of $4-5 \%$ of fish biomass. The water quality in aquarium kept through siphoning and changing the water as much as $30 \%$ from total volume of the aquarium every two days.

After 30 days of rearing, the challenge test was done through intramuscular injection of $A$. hydrophila into the fish body. The fish rearing during the challenge test lasted for 10 days. This study consisted of five treatments, they were K(normal catfish fed with feed without probiotic and not tested challenge), $\mathrm{K}+$ (normal catfish fed with feed without probiotic and tested challenge), $\mathrm{Np}$ (normal catfish fed with feed added with probiotics and tested challenge), G (gnotobiotic catfish fed with feed without probiotic and tested challenge), and $\mathrm{Gp}$ (gnotobiotic catfish fed with feed added probiotics and tested challenge).

\section{Growth parameters}

Survival rate (SR)

The survival rate of the experimental fish was observed at the end of the study that is calculated by using the following formula:

$$
\mathrm{SR}(\%)=\frac{\mathrm{Nt}}{\mathrm{No}} \times 100
$$

$\mathrm{SR}=$ Survival rate $(\%)$

$\mathrm{Nt}=$ The total fish at the end of the study

No $=$ The total fish at the initiation of the study

\section{Specific growth rate (SGR)}

The specific growth rate of the fish calculated based on the average weight of every 10 days during the fish rearing. The specific growth rate of the fish is calculated by using the following formula:

$$
\operatorname{SGR}(\%)=\left[\sqrt[t]{\frac{W t}{W o}}-1\right] \times 100
$$

$\mathrm{SGR}=$ Specific growth rate $(\% /$ day $)$

$\mathrm{Wt}=$ The average weight of fish at the end of study (g)

Wo $=$ The average weight of fish at the initiation of the study (g)

$\mathrm{t} \quad=$ Days of rearing

\section{Feed conversion ratio (FCR)}

The feed conversion ratio was observed during the rearing by calculating the amount of eaten feed. The feed conversion ratio is calculated using the following formula (Huisman, 1987):

$$
\mathrm{FCR}=\frac{\mathrm{F}}{\mathrm{Wt}+\mathrm{D}-\mathrm{Wo}}
$$

FCR $=$ Feed conversion ratio

$\mathrm{F} \quad=$ The amount of eaten feed $(\mathrm{g})$

$\mathrm{Wt}=$ The average weight of fish at the end of study (g)

Wo = The average weight of fish at the initiation of the study (g)

$\mathrm{D} \quad=$ The average weight of dead fish $(\mathrm{g})$

\section{The total amount of intestinal bacteria}

The total amount of bacteria in the digestive tract of fish is calculated by using TPC (total plate count) method. The calculation of the total amount of intestinal bacteria was done after 30 days of rearing and after 10 days of challenge test. The digestive tract of catfish as much as $1 \mathrm{~g}$ crushed and dissolved in $10 \mathrm{~mL}$ of sterile PBS, then it homogenized by using vortex and $0.85 \% \mathrm{NaCl}$ for serial dilution. The sample that has been diluted was scattered on TSA plate for obtaining total intestinal bacteria, in the other hand, MRSA used for total intestinal of LAB and MRSA with $50 \mu \mathrm{g} / \mathrm{mL}$ addition of rifampicin used for total probiotics bacteria, is incubated for 24 hours at room temperature, and the total of colonies was counted.

\section{Hematological parameters \\ Total erythrocyte}

Blood samples were sucked by using a pipette with a scale of 0.5 and was added with Hayem's solution up to 101. The blood and Hayem's solution in the pipette were shacked for 3-5 min in eight form until it got the homogeneity. The first drop was disposed and the following was dropped slowly to haemocytometer, covered it with a cover glass, and observed it by using a microscope. The calculation was performed in five different points of view of haemacytometer. The total erythrocyte is calculated using the following formula:

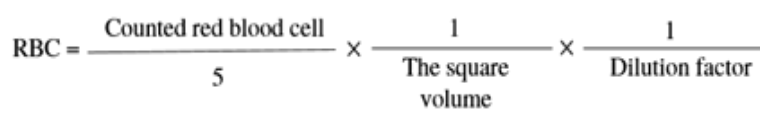

\section{Total leukocyte}

Blood samples were sucked by using a pipette with a scale of 0.5 and was added with Turk's solution up to the scale of 11 . The blood and Turk's solution in the pipette were shacked for 3-5 min in eight form until it got the homogeneity. The first drop was disposed and the following was dropped slowly to haemocytometer, covered it with a cover 
glass, and observed it by using a microscope. The calculation was performed in five different points of view of haemacytometer. The total leukocyte is calculated using the following formula:

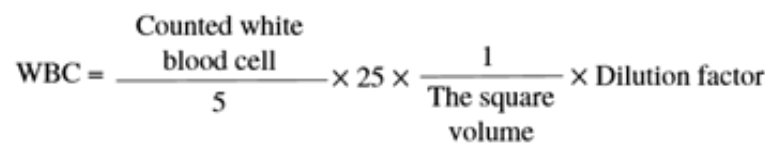

\section{Haemoglobin level}

Haemoglobin level $(\mathrm{Hb})$ measurement was carried out through Sahli method that converts blood into haematic acid (Gillet et al., 2009). Blood samples were sucked by using Sahli pipette to scale of $0.2 \mathrm{~mL}$, transferred it into Hb-meter tube that already filled with $\mathrm{HCl} 0.1 \mathrm{~N}$ to scale of 10 (red colored), stirred it, and rested for 3-5 min. Afterward, an aquades was added until the blood and $\mathrm{HCl}$ had the similar color to the indicator of $\mathrm{Hb}$-meter. The scale of matched color signified the haemoglobin level.

\section{Phagocytic activity of fish}

The phagocytic activity could be obtained from the capability of leukocyte cell to phagocyte the pathogen cell. Firstly, Staphylococcus aureus bacteria were cultured in tryptic soy broth (TSB) medium for 18 hours. After that, $10^{6} \mathrm{CFU} / \mathrm{mL}$ of bacteria and fish blood was taken as much as $50 \mu \mathrm{L}$ of it, mixed it, and was incubated at room temperature for $20 \mathrm{~min}$. Then the blood dropped slowly into slide glass, withdrawn it by using another slide glass with forming $45^{\circ}$, and finally drained it well. That sliding glass soaked with methanol for $10 \mathrm{~min}$ and drained it again before being wash with Giemsa solution for $10 \mathrm{~min}$. After all, it rinsed gently by using aquades and drained it again. Furthermore, it was observed by using a microscope. The phagocytic activity is calculated using the following formula:

$$
\text { Phagocytic index }=\frac{\sum \text { Phagocytizing cell }}{\sum \text { Phagocytic cell }} \times 100
$$

\section{Data analysis}

Survival rate data, specific growth rate, feed conversion ratio, the total number of bacteria, and the hematological parameters analyzed by analysis of variance (ANOVA). If it was a significant difference, it continuously performed with Duncan tested on $\alpha=0.05$. The data were analyzed by using SPSS 15.0 software.

\section{RESULTS AND DISCUSSIONS}

\section{Pathogenicity test}

In vitro tests in blood agar medium aimed to find out the haemolysis capability of bacteria isolates (Mangunwardoyo et al., 2010). The result of pathogenicity test from the sixth LAB isolates showed that all of that isolates in this study did not form a clear zone which on blood agar medium (Figure 1). It showed that all of six bacteria isolates were nonhaemolytic bacteria (able break down the erythrocytes). Suardana et al. (2014) reported that in some isolates, the formation of clear zone indicates the virulence of bacteria to break down the erythrocytes by extracellular bacteria protein substance known as haemolysin as an expression of its phenotype. The formation of widely clear zones on the blood agar medium showed the $\beta$-haemolysis activity in bacteria isolates. The result of this study was in accordance with Damodharan $e t$ al. (2015) that stated LAB does not generally have a haemolytic activity.

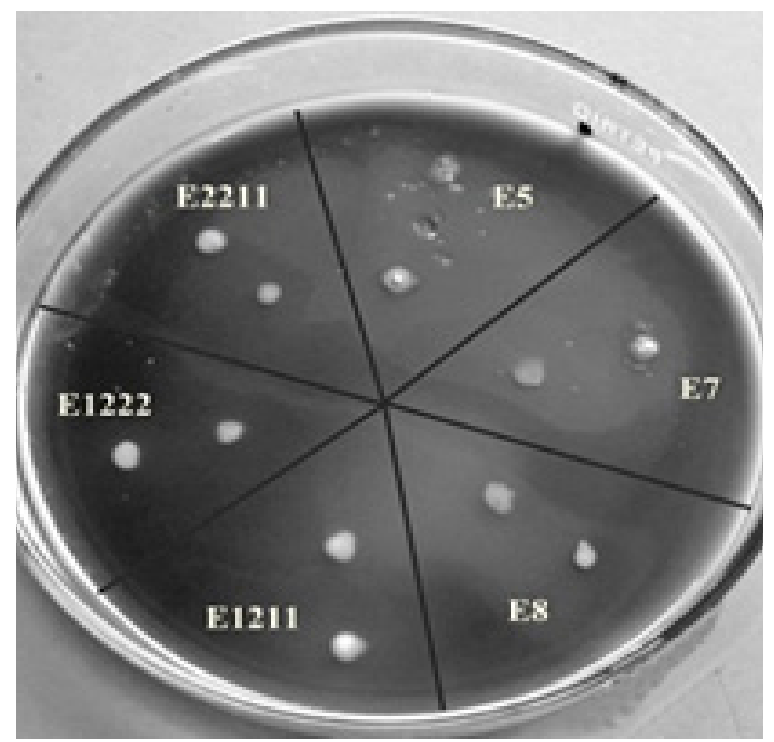

Figure 1. The result of pathogenicity test from six LAB isolates on blood agar medium

\section{Antagonistic test of lactic acid bacteria towards Aeromonas hydrophila}

The antagonistic test aims to find out at the ability of LAB isolates in producing antimicrobial compounds to inhibit the growth of $A$. hydrophila. The LAB isolates can produce various protein (polypeptide) substance that has antimicrobial activity i.e bacteriocin during the growth period (Zacharof \& Lovitt, 2012). The antagonistic activity was characterized by the formation of inhibitory zones around the spot on media after it giving LAB free cell supernatant at low $\mathrm{pH}$ and neutral $\mathrm{pH}(\mathrm{pH}$ 6.5). The LAB free cell supernatant treatment that was not neutralized aimed to maintain acidic conditions of organic acid compounds, while the neutralized 
Table 1. The index of supernatant inhibitor zone from the six isolates of lactic acid bacteria against Aeromonas hydrophila

\begin{tabular}{clccc}
\hline \multirow{2}{*}{ No. } & The isolates of lactic acid bacteria & \multirow{2}{*}{$\begin{array}{c}\text { Supernatant } \\
\text { initial } \mathrm{pH}\end{array}$} & \multicolumn{2}{c}{ The index of the inhibitory zone } \\
\cline { 4 - 5 } & & 3.96 & Initial $\mathrm{pH}$ & Neutralized $\mathrm{pH}(\mathrm{pH}$ 6.5) \\
\hline 1. & Lactobacillus plantarum $\mathrm{E} 1211$ & 3.92 & 0.184 & - \\
2. & Pediococcus petosaceus $\mathrm{E} 1222$ & 3.91 & 0.164 & - \\
3. & Pediococcus pentosaceus $\mathrm{E} 2211$ & 3.90 & 0.307 & - \\
4. & Pediococcus pentosaceus $\mathrm{E} 5$ & 3.99 & 0.195 & - \\
5. & Pediococcus pentosaceus $\mathrm{E} 7$ & 4.03 & 0.130 & - \\
6. & Pediococcus pentosaceus $\mathrm{E} 8$ & & \\
\hline
\end{tabular}

treatment of free cell supernatant aimed to eliminate the antibacterial influence of organic acid so that the active antibacterial substance was only the organic compounds (Puspita, 2011). All of LAB isolates showed the inhibitory activity against $A$. hydrophila towards low $\mathrm{pH}$, yet it has not shown the inhibitory activity at neutralized $\mathrm{pH}$ (Table 1). This was likely due to bacteriocin that produced was still not able to inhibit $A$. hydrophila in the density of $10^{6} \mathrm{CFU} /$ $\mathrm{mL}$ or the experimental bacterial isolates tend to produce organic acids. According to Khunajakr et al. (2008), LAB strain has the ability to produce organic acids that can potentially apply as probiotics. Lactic acid is able to weaken the permeability of bacteria especially in outer membranes of gram-negative bacteria through breaking down its part.

The repeat test conducted on selected three LAB isolates rely on its inhibitor zone. It was done by increasing the viscosity of supernatant concentration that produced on neutralized $\mathrm{pH}$ conditions. The observation result from the index of supernatant inhibitor zone against A. hydrophila showed the highest was LAB $P$. pentosaceus E2211, moreover, it was selected as probiotics candidate for catfish on the next experimental stages (Table 2). Rosyidah et al. (2013) reported that $P$. pentosaceus E2211 is one of LAB that was successfully isolated from the fermentation process (immersion) of corn spontaneously for 48 hours. $P$. pentosaceus E2211 is a gram-positive bacteria with coccusshaped and has negative catalase.

The growth curve of selected bacterial isolates

The curve of growing bacteria was observed through the increasing of optical density towards the time (Figure 2). The growth curves of $P$. pentosaceus E2211 has a lag phase (adaptation) about two hours of incubation period. The adaptation phase is an adjustment phase of the bacteria that already moved into a new medium with any different substrate and conditions of its environment (White, 2007). The time of this phase was varied, depending on the ability of bacteria to adapt to the surrounding environment. The second hour until the sixth hour of the cells entered the log phase (exponential) was characterized by increasing the OD significantly, the seventh hour to $18^{\text {th }}$-hour, the cells entered stationary phase and at $19^{\text {th }}$ hour and so on, the cells experienced the death phases, which was characterized by decreasing value of OD. Exponential phase is the phase of bacteria active growth, moreover, the cells mass increase exponentially towards the time, while the stationary phase is a stop phase of cells growth (White, 2007) with bacterial growth that tends to go slow and remain. The death phase is the phase of decreasing the number of bacterial cells because the bacteria dies after running out

Table 2. The index of supernatant inhibitor zone towards increasing the viscosity 25 times from the three isolates of lactic acid bacteria against Aeromonas hydrophila

\begin{tabular}{cccc}
\hline \multirow{2}{*}{\begin{tabular}{c} 
The supernatant \\
concentration $(\mathrm{pH} 6.5)$ \\
\cline { 2 - 4 }$(\mu \mathrm{L})$
\end{tabular}} & $\begin{array}{c}\text { The index of inhibitor zone } \\
\text { Peccus pentosaceus }\end{array}$ & $\begin{array}{c}\text { Pediococcus } \\
\text { pentosaceus } \text { E5 }\end{array}$ & Pediococcus pentosaceus E7 \\
\hline 25 & E2211 & - & - \\
50 & - & - & 0.093 \\
75 & 0.285 & 0.233 & 0.312 \\
100 & 0.427 & 0.312 & 0.457 \\
\hline
\end{tabular}




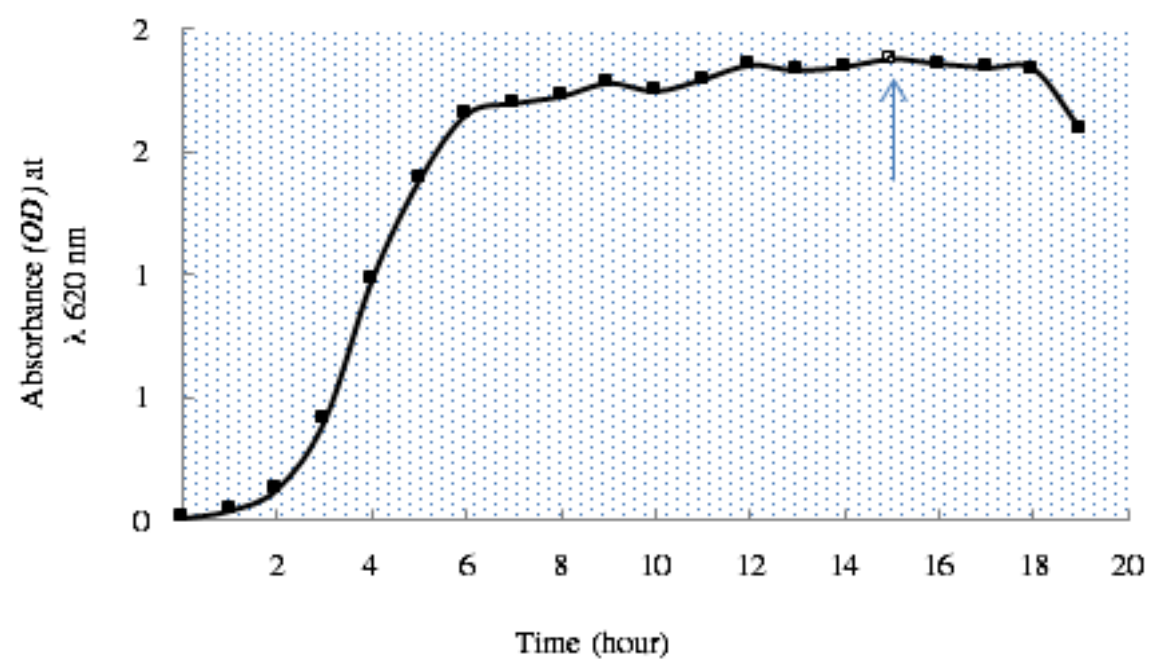

Figure 2. The growth curve of selected isolate $P$. pentosaceus in MRSB medium for 19 hours at $37^{\circ} \mathrm{C}$. The arrow showed the limit of bacterial growth zenith

of some nutrients and it is on the incompatible environmental conditions i.e an existence of toxic matter from bacterial metabolism during incubation (Klose et al., 2010). According to the growth curve that obtained from this study, the cells harvesting time for the next cells production on the next stages are performed on the exponential phase, or at the sixth hour.

\section{The viability of probiotic bacteria in fish feed}

The ability of probiotic bacteria to survive is known through testing the viability of probiotic in fish feed. The viability of fresh probiotics cultures during preparation and storage is the main thing in probiotic preparation (Wang et al., 2008) moreover the probiotics can be applied and provide benefits to its host. The density of probiotics $P$. pentosaceus E2211 that added into the feed for viability test is $10^{8}$ and $10^{10} \mathrm{CFU} / \mathrm{ml}$ (Table 3). Afrilasari et al. (2017) reported that the results of viability test of probiotic Bacillus megaterium PTB 1.4 (the density of $10^{8} \mathrm{CFU} /$ $\mathrm{mL}$ ) that added into feed is able to survive with a cell density of $10^{6} \mathrm{CFU} / \mathrm{mL}$ and significantly affect the total intestinal bacteria of catfish, while Zare et al. (2015) reported that the addition of probiotics Pediococcus acidilactici with density of $10^{10} \mathrm{CFU} / \mathrm{ml}$ also give the significant effects towards the total number of LAB in intestine.

The viability of LAB isolates $P$. pentosaceus
E2211 was still well even though it was either experienced a decreasing in the total number of bacteria after mixing feed. The decrease in the total number of bacteria due to the number of probiotics that added to feed as much as $1 \%$ in $100 \mathrm{~g}$ gained $0.01 \%$ of probiotics. It showed that $P$. pentosaceus can be applied as a probiotic in fish through the fish feed. P. pentosaceus has been widely applied as a feed additive in the United States, around Europe, China, Thailand, Australia, and New Zealand (Lim \& Tan, 2009). According to the results of the test, the viability of P. pentosaceus E2211 in feed, the density of $P$. pentosaceus E2211 that used in the in vivo test of catfish was $10^{8} \mathrm{CFU} / \mathrm{mL}$.

The determination of lethal dose $50\left(\mathrm{LD}_{50}\right)$ of Aeromonas hydrophila towards the catfish

The virulence of $A$. hydrophila can be known through the $\mathrm{LD}_{50}$ value is produced, it was the observation to a dose that capable to kill 50\% of the fish population. According to Rey et al. (2009), the infection of A. hydrophila can cause clinical symptoms after several hours of infection and the mortality began after 7 hours. The infection further will cause mortality after 12-24 hours. As for the densities of $A$. hydrophila used in the observation of $\mathrm{LD}_{50}$ test towards the catfish were $10^{5}, 10^{6}, 10^{7}$, and $10^{8}$ CFU/mL (Table 4).

Table 3. The viability of Pediococcus pentosaceus E2211 in fish feed

\begin{tabular}{ccc} 
Treatments & $\begin{array}{c}\text { The initial addition of bacteria } \\
(\mathrm{CFU} / \mathrm{mL})\end{array}$ & $\begin{array}{c}\text { The total probiotic bacteria after } 30 \mathrm{~min} \text { of } \\
\text { mixing }(\mathrm{CFU} / \mathrm{mL})\end{array}$ \\
\hline The $1^{\text {st }}$ viability test & $10^{8}$ & $5.4 \times 10^{6}$ \\
The $2^{\text {nd }}$ viability test & $10^{10}$ & $1.3 \times 10^{9}$ \\
\hline
\end{tabular}


Table 4 . The determination of lethal dose $50\left(\mathrm{LD}_{50}\right)$ of Aeromonas hydrophila towards the catfish

\begin{tabular}{|c|c|c|c|c|c|c|c|}
\hline \multirow{2}{*}{$\begin{array}{c}\text { Densities (CFU } \\
\mathrm{m} / \mathrm{L})\end{array}$} & \multirow{2}{*}{ Dead } & \multirow{2}{*}{ Live } & \multirow{2}{*}{$\begin{array}{l}\text { Mortality } \\
\text { ratio }\end{array}$} & \multicolumn{4}{|c|}{ Accumulation } \\
\hline & & & & Dead & Live & Mortality ratio & $\%$ of mortality \\
\hline $10^{8}$ & 10 & 0 & $10 / 10$ & 21 & 0 & $21 / 21$ & 100.00 \\
\hline $10^{7}$ & 8 & 2 & $8 / 10$ & 11 & 2 & $11 / 13$ & 84.61 \\
\hline $10^{6}$ & 3 & 7 & $3 / 10$ & 3 & 9 & $3 / 12$ & 25.00 \\
\hline $10^{5}$ & 0 & 10 & $0 / 10$ & 0 & 19 & $0 / 19$ & 0.00 \\
\hline
\end{tabular}

According to the fish mortality pattern, after the fish injected with $A$. hydropila, it can be seen that the higher the density of A. hydrophila is injected then so does the mortality rate of fish. The density of bacteria that cause $50 \%$ of mortality in fish population within 5 days of incubation was $10^{6} \mathrm{CFU} / \mathrm{mL}$. According to $\mathrm{LD}_{50}$ test that has been performed, it obtained that the concentration of $A$. hydrophila was $10^{6} \mathrm{CFU} /$ $\mathrm{mL}$ used for challenge test. Triyaningsih et al. (2014) stated that the $\mathrm{LD}_{50}$ value can indicate the level of virulence from the bacteria. Bacteria that has a $\mathrm{LD}_{50}$ value between $10^{4.5}-10^{5.5} \mathrm{CFU} /$ $\mathrm{mL}$ belongs to a high virulent group of bacteria; an $\mathrm{LD}_{50}$ value between $10^{5.5}-10^{7} \mathrm{CFU} / \mathrm{mL}$ belongs to a virulent group of bacteria; and $\mathrm{LD}_{50}$ more than $10^{7} \mathrm{CFU} / \mathrm{mL}$ is an avirulent group of bacteria.

\section{The growth performance of catfish}

The growth performance of catfish after in vivo test was showed through its survival rate after 30 days of rearing, the specific growth rate, and the feed conversion ratio. The survival rate of catfish at all the treatments during the 30 days of rearing was $100 \%$. This showed that the treatment of gnotobiotic and probiotic during this study was safe for catfish. Probiotic treatment produced the highest SGR compared to other treatments, but the FCR was not significantly different $(\mathrm{P}>0.05)$ with other treatments (Figure 3 ; Table 4). The specific growth rate of all the treatments tended to experience an increasing at 10, 20, and 30 days of rearing. During 10 days of rearing, the SGR value of gnotobiotic catfish $(\mathrm{G}$ and $\mathrm{Gp}$ ) was lower than the controls (K- and $\mathrm{K}+$ ). This indicated that the gnotobiotic catfish was still in its recovery time after various antibiotics treatment so that the result of the SGR value was still low. At $20^{\text {th }}$ day of rearing, there was a significant difference between the $\mathrm{Np}$ treatment $(2.70 \pm 0.24)$ with $\mathrm{K}$ - treatment $(2.12 \pm 0.14)$. The highest SGR value after 30 days of rearing was $\mathrm{Np}$ treatment that significantly different $(\mathrm{P}$ $<0.05$ ) with four other treatments.

$\mathrm{Np}$ treatment was a treatment feed with the addition of probiotic P. pentosaceus E2211. This is indicated that the presence of probiotics $P$. pentosaceus E2211 was capable to associate with intestinal microflora in increasing the nutrients absorption thus increasing the specific growth rate of fish. The improvement of fish growth after probiotic treatment occurred due to the increase of appetite and digestibility of fish. The increasing of fish digestibility that fed with probiotics occurred because the probiotic synthesized the extracellular enzymes such as protease, amylase, and lipase, and a gr owth factor such as vitamins, fatty acids, and amino acids (Sahu et al., 2008). Xing et al. (2013) reported that fed supplementation of $P$. pentosaceus $\left(10^{9}\right.$ $\mathrm{CFU} / \mathrm{g}$ ) in cobia fish (Rachycentron canadum) for two weeks showed a better growth than the control.

The higher growth in probiotic treatment associated with intestinal bacteria of experimental fish. The highest total number of intestinal bacteria, total LAB, and total probiotic of $P$. pentosaceus E2211 obtained at $\mathrm{Np}$ treatment that significantly different $(\mathrm{P}<0.05)$ with the other treatments (Table 6). This was because in addition to the capability of bacteria to colonize optimally, the probiotic $P$. pentosaceus E2211 was also capable to associate with LAB microflora in the catfish's intestine so it experienced an increasing the amount of LAB in the intestine and suppressed the pathogenic bacteria. According to Hegarty (1999) the ability of probiotics in improving the performance of the growth of its host can be seen from the microbial community in its intestine. The balance of the intestinal microflora can cause the probiotic reported that the addition of the LAB probiotic Lactobacillus sp. is able to increase the number of intestinal bacteria at the end of rearing.

The existence of LAB probiotic can balance the digestion microbes through growth induction of good bacteria and inhibit pathogenic bacteria through the of lactic acid production that is bactericidal (Askarian et al., 2011). The LAB group can also produce acetic acid, hydrogen 
Table 5. The survival rate and feed conversion ratio of catfish feed after 30 days of rearing

\begin{tabular}{ccc}
\hline Treatments & Survival rate $(\%)$ & Feed conversion ratio \\
\hline K- & $100 \pm 0.00^{\mathrm{a}}$ & $1.95 \pm 0.09^{\mathrm{a}}$ \\
K+ & $100 \pm 0.00^{\mathrm{a}}$ & $1.99 \pm 0.06^{\mathrm{a}}$ \\
Np & $100 \pm 0.00^{\mathrm{a}}$ & $1.78 \pm 0.13^{\mathrm{a}}$ \\
$\mathrm{G}$ & $100 \pm 0.00^{\mathrm{a}}$ & $2.03 \pm 0.24^{\mathrm{a}}$ \\
Gp & $100 \pm 0.00^{\mathrm{a}}$ & $1.94 \pm 0.09^{\mathrm{a}}$ \\
\hline
\end{tabular}

Note: The numbers that followed with the same superscripts in the same column showed significantly different according to Duncan test at a confidence level of $\alpha 0.05$

peroxide, and bacteriocin that can suppress the growth of competitors bacteria (Castex et al., 2008; Maeda et al., 2013). Moslehi et al. (2016) reported that $P$. pentosaceus is capable to colonize well in the digestive tract of Siberian sturgeon (Acipenser baerii Brandt, 1869) with the highest total of $P$. pentosaceus in intestine obtained at the treatment with doses of $2 \times 10^{9}$ CFU/g. The ability of bacteria to colonize well in the digestive tract of fish caused by the $P$. pentosaceus has the ability to survive to pass the fish gut with low $\mathrm{pH}$ and bile salt with an alkaline pH (Maji et al., 2016).

The survival rate and hematological parameters of catfish after challenge test with Aeromonas hydrophila

The survival rate of catfish after challenge test at the probiotics treatment ( $\mathrm{Np}$ and $\mathrm{Gp}$ ) was significantly different $(\mathrm{P}<0.05)$ compared with the treatment without probiotics (Figure 4). The $\mathrm{Np}$ and Gp treatment can reach the survival rate of $88.46 \%$ higher compared to $\mathrm{K}+(53.84 \%)$ and $\mathrm{G}(65.38 \%)$. This was because the probiotics $P$. pentosaceus E2211 produces an antibacterial substance against $A$. hydrophila that was shown in inhibit zone at antagonistic test against $A$. hydrophila. Antimicrobial activity of LAB against pathogenic bacteria is due to the production of organic acids, hydrogen peroxide, and bacteriocin (Vesterlund, 2009).

Damodharan et al. (2015) reported that the antimicrobial activity of $P$. pentosaceus KID7 against gram-positive and gram-negative bacteria comes from organic acid production. $P$. pentosaceus has an activity of anti-A. hydrophila through the production of the extracellular product (ECP) that produces the maximum antagonistic activity in inhibit zone as much as 9 to $10 \mathrm{~mm}$, and it can still be maintained at $\mathrm{pH}$ 7-9. According to Soltani et al. (2015), with the anti-A. hydrophila in $P$. pentosaceus, it helps the probiotics to pass through the digestive tract of fish and colonize dominate in the intestine of fish thus suppressing the growth of A. hydrophila and other various pathogens in the intestine while enhancing the immunity of fish so that it can increase the survival rate of fish higher than

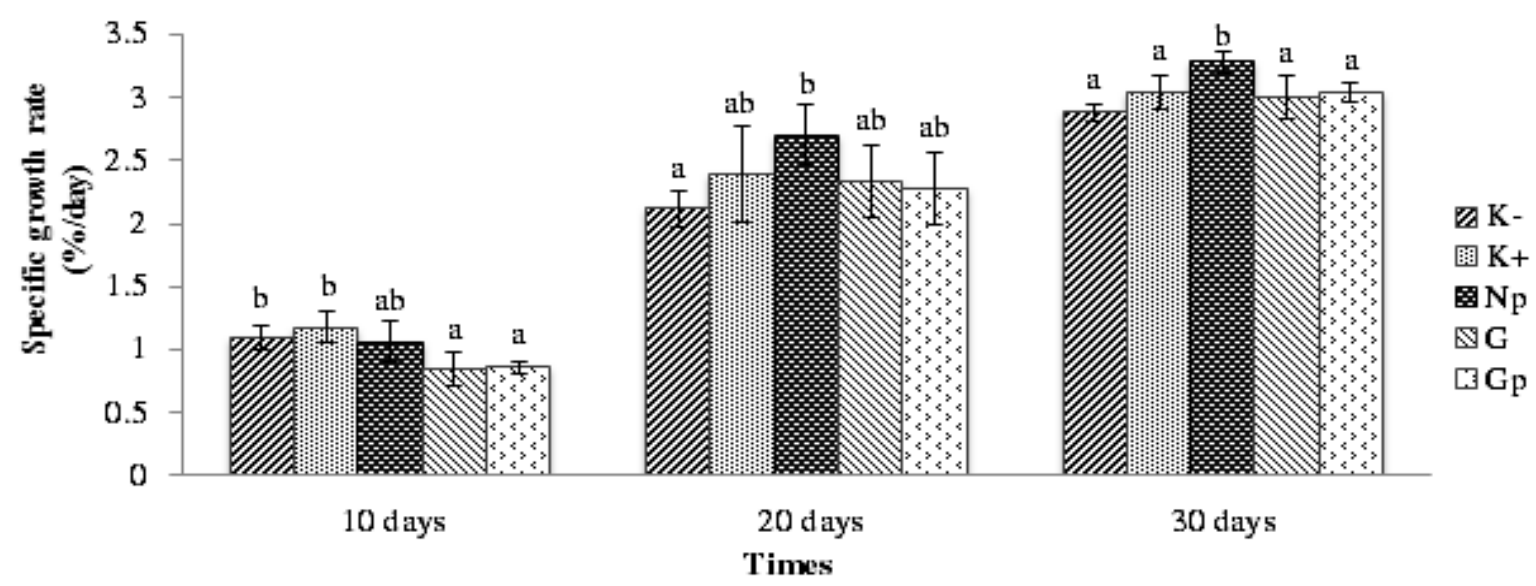

Figure 3. The specific growth rate (SGR) of catfish at 10, 20, 30 days of rearing. K- (normal catfish without addition probiotic, without challenge test), $\mathrm{K}+$ (normal catfish without addition of probiotic, with challenge test), $\mathrm{Np}$ (normal catfish with addition of probiotic and challenge test), G (gnoto catfish without addition of probiotic, with challenge test), and Gp (gnoto catfish with addition of probiotic and challenge test). The same superscripts showed the significantly different result according to Duncan test at a confidence level of $\alpha 0.05$ 
Table 6. The total amount of bacteria in the digestive tract of catfish after 30 days of rearing

\begin{tabular}{cccc}
\hline Treatments & $\begin{array}{c}\text { The total amount of intestinal } \\
\text { bacteria }\left(10^{7} \mathrm{CFU} / \mathrm{mL}\right)\end{array}$ & $\begin{array}{c}\text { The total lactic acid of intestinal } \\
\text { bacteria }\left(10^{6} \mathrm{CFU} / \mathrm{mL}\right)\end{array}$ & $\begin{array}{c}\text { Total probiotic } \\
\left(10^{5} \mathrm{CFU} / \mathrm{mL}\right)\end{array}$ \\
\hline $\mathrm{K}-$ & $7.03 \pm 1.50^{\mathrm{a}}$ & $0.42 \pm 0.10^{\mathrm{a}}$ & $0.00 \pm 0.00^{\mathrm{a}}$ \\
$\mathrm{K}+$ & $8.19 \pm 0.97^{\mathrm{a}}$ & $0.49 \pm 0.05^{\mathrm{a}}$ & $0.00 \pm 0.00^{\mathrm{a}}$ \\
$\mathrm{Np}$ & $23.38 \pm 12.95^{\mathrm{b}}$ & $59.0 \pm 26.45^{\mathrm{b}}$ & $46.5 \pm 15.97^{\mathrm{b}}$ \\
$\mathrm{G}$ & $0.03 \pm 0.003^{\mathrm{a}}$ & $0.01 \pm 0.006^{\mathrm{a}}$ & $0.00 \pm 0.00^{\mathrm{a}}$ \\
$\mathrm{Gp}$ & $1.33 \pm 0.59^{\mathrm{a}}$ & $11.7 \pm 7.64^{\mathrm{a}}$ & $7.396 \pm 1.24^{\mathrm{a}}$ \\
\hline
\end{tabular}

Note: K- (normal catfish without addition probiotic, without challenge test), K+ (normal catfish without addition of probiotic, with challenge test), $\mathrm{Np}$ (normal catfish with addition of probiotic and challenge test), G (gnoto catfish without addition of probiotic, with challenge test), and $\mathrm{Gp}$ (gnoto catfish with addition of probiotic and challenge test). The numbers that followed with the same superscripts in the same column showed significantly different according to Duncan test at a confidence level of $\alpha 0.05$.

the fish without probiotics.

The survival rate after challenge test was higher on catfish fed with probiotic treatment (Np and $\mathrm{Gp}$ ) than the $\mathrm{K}+$ treatment (Figure $5 \mathrm{a}, \mathrm{b}, \mathrm{c}$, and d), it was also supported by the hematological parameters (total erythrocytes, total leukocytes, haemoglobin, and phagocytic activity after challenge test). The existence of probiotics $P$. pentosaceus E2211 can assist and accelerate the recovery process of fish by increasing the non-specific immune response and the resistance against MAS. The fish haematological parameters in this study were been in normal range of the total erythrocyte $\left(1.3 \times 10^{6}\right.$ cells $\left./ \mathrm{mm}^{3}\right)$, the total leukocytes $\left(2.15 \times 10^{4}\right.$ cells $\left./ \mathrm{mm}^{3}\right)$, and the haemoglobin (6.10 g/dL) (Svobodova \& Vyukusova, 1991; Takashima \& Hibiya 1995).

Soltani et al. (2015) reported that the addition of Lactococcus lactis probiotics (JF831150) proved to be able to increase total leukocyte, erythrocytes, and haemoglobin of
Persian sturgeon (Acipenser persicus). The total erythrocytes and haemoglobin that was higher at the addition of probiotics treatment than $\mathrm{K}+$ indicated that $P$. pentosaceus E2211 was able to maintain the fish health status, by keeping the total erythrocytes and haemoglobin in the normal range after $A$. hydrophila infection. The high amount of total leukocytes and phagocytic activity in $\mathrm{Gp}$ and $\mathrm{Np}$ treatment showed that the existence of probiotic was able to induce the production of leukocytes in a massive amount against $A$. hydrophila infection. The existence of normal microflora in association with $P$. pentosaceus E2211 in $\mathrm{Np}$ treatment was able to increase the immunity of fish better than $P$. pentosaceus E2211 in Gp treatment.

Sukenda et al. (2016), stated that the increase of total leukocytes caused by the response from the fish body against infectious diseases. Leukocyte cell is a phagocytes cell to prevent unwanted bacteria and spread the virulence factors in the fish body. The part of leukocyte

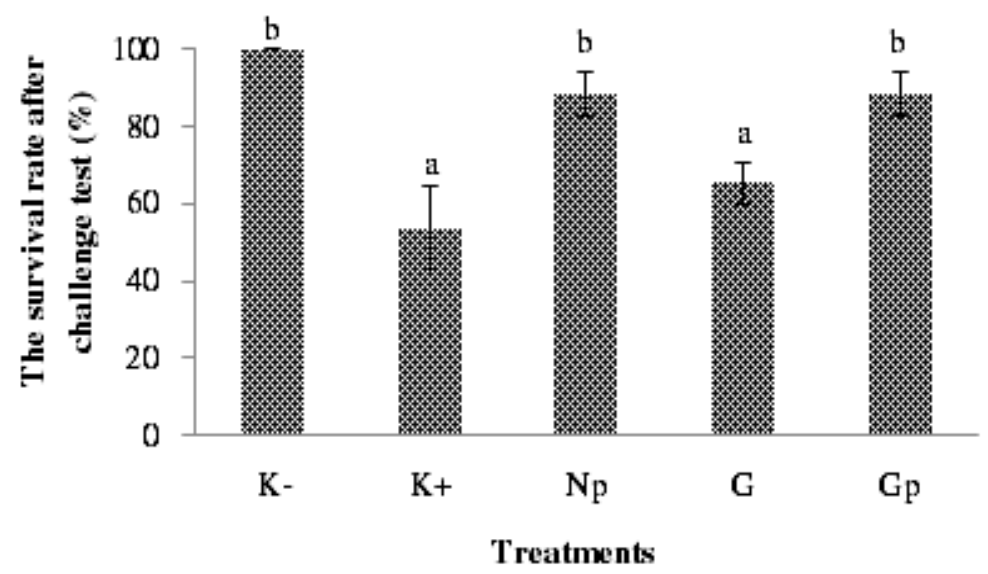

Figure 4. The survival rate of catfish after 10 days of challenge test. K- (normal catfish without addition probiotic, without challenge test), $\mathrm{K}+$ (normal catfish without addition of probiotic, with challenge test), Np (normal catfish with addition of probiotic and challenge test), $\mathrm{G}$ (gnoto catfish without addition of probiotic, with challenge test), and $\mathrm{Gp}$ (gnoto catfish with addition of probiotic and challenge test). The same superscripts showed the significantly different result according to Duncan test at a confidence level of $\alpha 0.05$ 

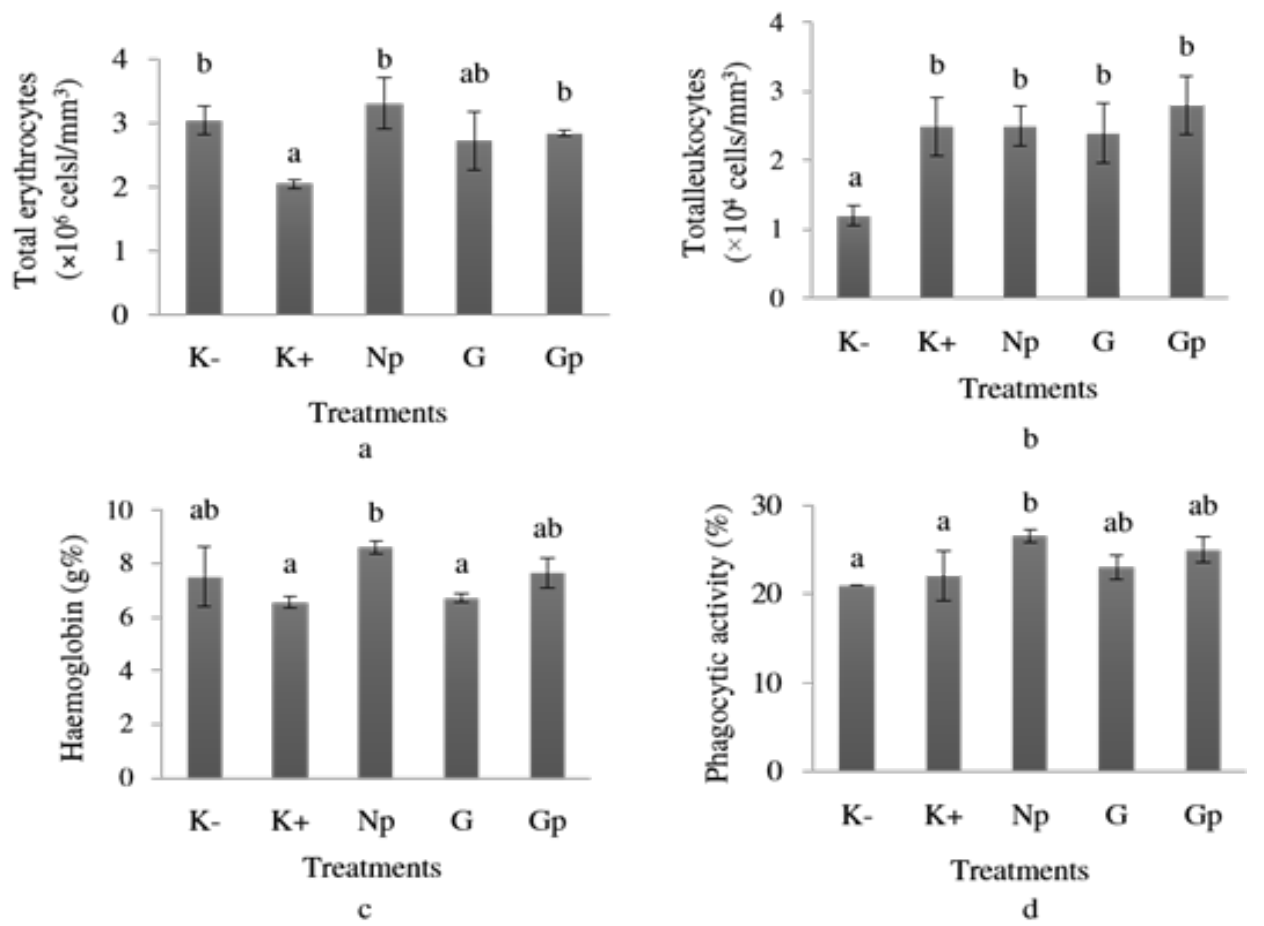

Figure 5. The hematological parameters of catfish after 10 days of challenge test: (a) The total erythrocytes; (b) The total leukocytes; (c) Haemoglobin; (d) Phagocytic activity. K- (normal catfish without addition probiotic, without challenge test), $\mathrm{K}+$ (normal catfish without addition of probiotic, with challenge test), Np (normal catfish with addition of probiotic and challenge test), $\mathrm{G}$ (gnoto catfish without addition of probiotic, with challenge test), and $\mathrm{Gp}$ (gnoto catfish with addition of probiotic and challenge test). The same superscripts showed the significantly different result according to Duncan test at a confidence level of $\alpha 0.05$.

cell that according to with the function are monocytes and neutrophils that indicated by the value of phagocytic activity (Utami et al., 2015). Monocytes and neutrophils are the components of blood cells that generate superoxide anion $\left(\mathrm{O}_{2}{ }^{-}\right)$, hydrogen peroxide $\left(\mathrm{H}_{2} \mathrm{O}_{2}\right)$, nitric oxide (NO), peroxide nitrite (ONOO-), hypochlorite acid $(\mathrm{HOCl})$, and hydroxyl radical $\left(\mathrm{OH}^{-}\right)$that have the high ability to kill microbes (Ellis, 2001).

\section{CONCLUSION}

The selected LAB isolates of $P$. pentosaceus E2211 is potential for probiotics candidate in normal catfish and gnotobiotic catfish (Clarias $\mathrm{sp}$.), that indicated by the survival rate of $\mathrm{Np}$ and Gp treatment after challenge test, it was $88.46 \%$, while $\mathrm{K}+$ and $\mathrm{G}$ were only reached $53.84 \%$ and $65.38 \%$. The performance of $P$. pentosaceus E2211 as probiotics was showed through its ability to maintaining the survival rate, the specific growth rate, the total intestinal bacteria, and the immune response of catfish to A. hydrophila infection. The existence of normal microflora in association with $P$. pentosaceus E2211 in Np treatment showed the best performance of probiotic with $3.28 \%$ / day of the specific growth rate, 1.78 of the feed conversion ratio, and the total intestinal bacteria reached $10^{8} \mathrm{CFU} / \mathrm{mL}$.

\section{ACKNOWLEDGMENT}

This study was funded by Prof. Dr. Anja Meryandini, MS through the funding of Penelitian Strategis Aplikasi year 2016 from Ministry of Research, Technology, and Higher Education of the Republic of Indonesia Number 079/SP2H/LT/ DRPM/II/2016.

\section{REFERENCES}

Afrilasari W, Widanarni, Meryandini A. 2017. Effect of probiotic Bacillus megaterium ptb 1.4 on the population of intestinal microflora, digestive enzyme activity, and the growth of catfish Clarias sp.. Hayati Journal of Biosciences 30: 1-5.

Anyanwu MU, Chan KF, Shoyianka VS. 2015. Evaluation of pathogenicity of motile Aeromonas species in African catfish. Internasional Journal Fisheries and Aquatic Studies 2: 93-98.

Askarian F, Kousha A, Salma W, Ring E. 2011. The effect of lactic acid bacteria 
administration on growth, digestive enzyme activity and gut microbiota in Persian sturgeon Acipenser persicus and beluga Huso huso fry. Aquaculture Nutrition 17: 488-495.

Castex M, Chim L, Pham D, Lemaire P, Wabete N, Nicolas JL, Schmidely P, Mariojouls C. 2008. Probiotic P. acidilactici application in shrimp Litopenaeus stylirostris culture subject to vibriosis in New Caledonia. Aquaculture 275: 182-193.

Damodharan K, Lee YS, Palaniyandi S, Yang SH, Suh J. 2015. Preliminary probiotic and technological characterization of Pediococcus pentosaceus strain KID7 and in vivo assessment of its cholesterol-lowering activity. Frontiers in Microbiology 6: 768-783.

Ellis AE. 2001. Innate host defense mechanisms of fish against viruses and bacteria. Developmental and Comparative Immunology 25: 827-839.

Gatesoupe FJ. 1999. The use of probiotics in aquaculture. Aquaculture 180: 147-165.

Gillet P, Boei L, Jacobs J. 2009. Practical Note: Tropical Haematology. Antwerpen: Prince Leopold Institute of Tropical Medicine.

Gomez NC, Ramiro JM, Quecan BX, de Melo Franco B. 2016. Use of potential probiotic lactic acid bacteria (lab) biofilms for the control of Listeria monocytogenes, Salmonella typhimurium, and Escherichia coli O157:H7 biofilms formation. Frontiers in Microbiology 7: 863-870.

Hao H, Cheng G, Iqbal Z, Ai X, Hussain H, Huang L, Dai M, Wang Y, Liu Z, Yuan Z. 2014. Benefits and risks of antimicrobial use in food-producing animals. Frontiers in Microbiology 5: 1-11.

Hegarty JW, Guinane CM, Ross RP, Hill C, Cotter PD. 2016. Bacteriocin production: a relatively unharnessed probiotic trait. F1000 Research 5: 2587-2595.

Khunajakr N, Wongwicharn A, Moonmangmee D, Tantipaiboonvut S. 2008. Screening and identification of lactic acid bacteria producing antimicrobial compunds from pig gastrointestinal tracts. KMITL Science and Technology Journal 8: 8-17.

[KKP] Kementerian Kelautan dan Perikanan. 2014. Perikanan budidaya Indonesia. Direktorat Jendral Perikanan Budidaya. http://www.djpb.kkp.go.id/index.php/search/ c/9/?keyword=ikan+lele. [2017 Juni 13]

Klose V, Bayer K, Bruckbeck R, Schatzmayr G. 2010. In vitro antagonistic activities of animal intestinal strainst agains swine-associated pathogens. Veterinary Microbiology 144: 515-521.

Kusdarwati R, Kismiyati, Sudarno, Kurniawan H, Prayogi YT. 2017. Isolation and identification of Aeromonas hydrophila and Saprolegnia sp. on Catfish Clarias gariepinus in floating cages in Bozem moro, Krembangan Surabaya. IOP Conference Series: Earth and Environmental Science 55: 1-7.

Lim A, Tan H-M. 2009. Probiotics legal status and regulatory issues section 1.8.2. Animal probiotics. Di dalam: Lee YK, Salminen S, editor. Handbook of Probiotics and Prebiotics. Hoboken (US): John Wiley \& Sons, Inc.

Lukistyowati I, Kurniasih. 2012. Detection of aerolysin gen from Aeromonas hydrophila in common carp fed with garlic extract. Jurnal Veteriner 13: 43-50.

Maeda M, Shibata A, Biswas G, Korenaga H, Kono T, Itami I, Sakai M. 2014. Isolation of lactic acid bacteria from kuruma shrimp Marsupenaeus japonicus intestine and assessment of immunomodulatory role of a selected strain as probiotic. Marine Biotechnology 16: 181-192.

Maji UJ, Mohanty S, Mahapatra AS, Maiti NK. 2016. Diversity and probiotic potentials of putative lactic acid bacteria for application in freshwater aquaculture. Turkish Journal of Fisheries and Aquatic Sciences 16: 805-818.

Mangunwardoyo W, Ismayasari R, Riani E. 2010. Pathogenicity and virulency of Aeromonas hydrophila stainer on Nile tilapia Oreochromis niloticus Lin. using Koch postulate. Jurnal Riset Akuakultur 5: 245-255.

Martin R, Bermudez-Humaran LG, Langella P. 2016 Gnotobiotic rodents: an in vivo model for the study of microbe-microbe interactions. Frontiers in Microbiology 7:1-7.

Moslehi F, Sattari M, Masouleh AS. 2016. Effects of Pediococcus pentosaceus as a probiotic on intestinal microbiota and body composition of Siberian sturgeon Acipenser baerii Brandt, 1869. International Journal Aquaculture Biology 4: 11-16.

Parameswari W, Sasanti A, Muslim. 2013. Bacteria population, histology, survival rate and growth of snakehead Channa striata fry maintained in media with addition of probiotics. Jurnal Akuakultur Rawa Indonesia 1: 76-89.

Puspita IR. 2011. Penapisan antibakteri yang dihasilkan oleh bakteri asam laktat dari produk 
bekasam ikan seluang Rasbora argyrotaenia [Skripsi]. Bogor (ID): Institut Pertanian Bogor. Quinto EJ, Jimenez P, Caro I, Tejero J, Mateo J, Girbes T. 2014. Probiotic lactic acid bacteria: a review. Food and Nutrition Sciences 5: 1765-1775.

Rey A, Verjan N, Ferguson HW, Iregui C. 2009. Patogenesis of Aeromonas hydrophila strain KJ99 infection and its extrasellular product in two species of fish. Veterinary Record 164: 493-499.

Rosyidah E, Meryandini A, Sunarti TC. 2013. The use of lactic acid bacteria and cellulolytic bacteria to improve the chemical properties of corn flour. Makara Journal Science 17: 75-80.

Sahu MK, Swarnakumar NS, Sivakumar K, Thangaradjou T, Kannan L. 2008. Probiotics in aquaculture: importance and future perspectives. Indian Journal of Microbiology 48: 299-302.

Situmorang ML, Dierckens K, Mlingi FT, Delsen BV, Bossier P. 2014. Development of a bacterial challenge test for gnotobiotic Nile tilapia Oreochromis niloticus larvae. Diseases of Aquatic Organisms 109: 23-34.

Soltani M, Masouleh AS, Ahmadi M, Pourkazemi M, Taherimirghaed. 2015. Antibacterial activity, antibiotic suspectibility and probiotic use of lactic acid bacteria (LAB) in Persian sturgeon Acipenser persicus. Iranian Journal of Aquatic Animal Health 2: 54-65.

Sukenda, Rafyanzani MM, Rahman, Hidayatullah D. 2016. Performance of Bacillus sp. probiotic in catfish juvenile Clarias sp. infected by Aeromonas hydrophila. Jurnal Akuakultur Indonesia 15: 162-170.

Suardana IW, Utama IH, Wibowo MH. 2014. Identification of Escherichia coli O157:H7 from chicken feces and test of hemolytic profile on blood agar medium. Jurnal Kedokteran Hewan 8: 1-5.

Suskovic J, Kos B, Beganovic J, Pavunc AL, Habjanic K, Matosic S. 2010. Antimicrobial activity-the most important property of probiotic and starter lactic acid bacteria. Food Technology and Biotechnology 48: 296-307.

Svobodova Z, Vyukusova B. 1991. Diagnostic, Prevention and Therapy of Fish Disease and Intoxication. Jerman: Research Institute of fish Culture and Hydrobiology.

Takashima, F, Hibiya, T. 1995. An Atlas of Fish Histology: Normal and Pathological Features. Tokyo: Kodansa LTD.
Tambekar DH, Bhutada SA. 2010. An evaluation of probiotic potential of Lactobacillus sp. from milk of domestic animals and commercial available probiotic preparations in prevention of enteric bacterial infections. Recent Research Science and Technology 2: 82-88.

Triyaningsih, Sarjito, Prayitno SB. 2014. Pathogenicity Aeromonas hydrophila isolated from catfish Clarias gariepinus from Boyolali. Journal of Aquaculture Management and Technology 3: 11-17.

Utami DAS, Widanarni, Suprayudi MA. 2015. Administration of microencapsulated probiotic at different doses to control streptococcosis in tilapia Oreochromis niloticus. Microbiology Indonesia 9: 17-24.

Vesterlund S. 2009. Mechanism of probiotics: production of antimicrobial substances. Di dalam: Lee YK, Salminen S, editor. Handbook of Probiotics and Prebiotics. Hoboken (US): John Wiley \& Sons Inc.

Wahjuningrum D, Astrini R, Setiawati M. 2013. Prevention of Aeromonas hydrophila infection on 11-day-old catfish Clarias sp.juvenile using garlic Allium sativum and meniran Phyllanthus niruri. Jurnal Akuakultur Indonesia 12: 94104.

Wang YB. 2007. Effect of probiotics on growth performance and digestive enzyme activity of the shrimp Penaeus vannamei. Aquaculture 269: 259-264.

Wang YB, Li JR, Lin J. 2008. Probiotics in aquaculture: Challenges and outlook. Aquaculture 281: 1-4.

White D. 2007. The Physiology and Biochemistry of Prokaryotes. Third Edition. New York: Oxford University Press.

Xing $\mathrm{CF}$, Hu HH, Huang JB, Fang $\mathrm{HC}$, Kai YH, Wu YC, Chi SC. 2013. Diet supplementation of Pediococcus pentosaceus in cobia Rachycentron canadum enhances growth rate, respiratory burst and resistance against photobacteriosis. Fish \& Shellfish Immunology 35: 1122-1128.

Zacharof MP, Lovitt RW. 2012. Bacteriocins produced by lactic acid bacteria a review article. Science Direct 2: 50-56.

Zare A, Azari-Takami G, Taridashti F, Khara H. 2017. The effects of Pediococcus acidilactici as a probiotic on growth performance and survival rate of great sturgeon Huso huso Linnaeus, 1758. Iranian Journal of Fisheries Sciences 16: 150-161. 